\title{
RENAISSANCE EN REFORMASIE
}

\section{Tydgenote - nie Bondgenote}

B. J. van der Walt, MA, Th.B, D. Phil.

Calvyn as reformator kan alleen grondig verstaan en reg gewaardeer word as die agtergrond waarin hy opgegroei, ontwikkel gedink en geskryf het, ook in berekening gebring word.

Die sestiende eeuse dekor warteen sy lewe afspeel, is egter uitermate ingewikkeld. Op kerklike-godsdienstige, sosiaal-politiese, wysgerig-teologiese gebied tref ons 'n ontsettende verskeidenheid faktore aan wat in berekening gebring moet word.

Binne elk van die drie strominge waaroor ons gaan handel is daar groot verskeidenheid. Afgesien daarvan is daar tussen die verskillende strominge intieme wisselwerking: Renaissance, Humanisme en Stǒsisme kan net agteraf in die studeerkamer netjies uitmekaar gehaal word.

In wat hier volg, probeer ek slegs die diepste religieuse dryfveer agter Renaissance en Reformasie na vore bring.

1. Die sestiende eeu: skeiding van die geeste

Die woeling op verskeie terreine was reeds in die laat Middeleeue merkbaar. Die sestiende eeu word 'n onrustige tyd van "Sturm und Drang" met talle ingrypende gebeurtenisse; herhaalde pesepidemies, agrariese en ekonomiese krisisse en grootskaalse verstedeliking met die gepaardgaande sosiale gevolge daarvan.

'n Nuwe middelklas van handelslui ontstaan, die boere kom in opstand teen veronregting ...

Dit was egter ook 'n eeu van ongekende horisonverbreding. Behalwe die kompas en buskruit word ook ou-ou manuskripte weer ontdek en bestudeer. Deur die ontdekkingsreise word die wêreldkaart vergroot; die gebruik van papier en (beweeglike) boekdrukkuns, die ontstaan van skole en ontwikkeling van universiteite, nuwe denkbeelde (soos die van Copernicus) laat 'n nuwe wêreld gebore word.

En die geestelike leiers is bewus daarvan. Teenoor die donker Middeleeue sien hulle hulle eie tyd as 'n goue eeu, 'n nuwe era van lig en verligting.

By die oggendrooi van die nuwe era in die Westerse kultuurgeskiedenis ontstaan verskillende geestesstrominge elkeen met die pretensie dat hỳ die lig kan bied wat nodig is, dat hy alleen weer nuwe sekerheid en vastigheid aan die Europese mens kan gee.

Wie sy seismograaf fyn instel en mooi luister wat hier gebeur, sien duidelik dat die weë hier uitmekaar gaan. Die sestiende eeu is die bدgin van die einde van die groot rol wat die Christendom ongeveer duisend jaar lank $( \pm 500- \pm 1500)$ in die Weste gespeel het. Hier neem die sekularisering van die Weste 'n aanvang. 'n Nuwe paganisme word gebore. Aanvanklik is dit nog onvas op die bene, met slaap in die oë, maar spoedig sou dit die Westerse wêreld stormenderhand verower.

Ten spyte van die gemeenskaplike onvergenoegdheid met die skolastieke verlede gaan die weë stadig maar seker steeds duideliker 
uiteen. Die Renaissance breek met die sintesementaliteit, omdat hy die Bybels-Christelike element daarin nie kon duld nie. Vir die Reformasie is die sintese tussen Christendom en heidense denke nie langer aanvaarbaar nie, aangesien die Woord van God nie daarin tot sy reg kom nie.

Oor die vraag by watter bron die lig vir hierdie nuwe tyd aangesteek moet word, bestaan daar dus ook nie eenstemmigheid nie. Ons sou die Renaissance die fakkeldraer van Kain en die Reformasie die fakkeldraer van Abel kan noem.

\section{Die Renaissance: fakkeldraer van Kain}

Reeds by die vroeë of sogenaamde Christelike Humanisme en die denkers van die pre-Reformasie sien ons die verskil. Albei wil die fakkel vir die nuwe tyd in die verlede, by die Kersvaders gaan opsteek. Die motief is egter verskillend: die voorlopers van die Reformasie gryp na die Patristiek terug, omdat hulle deur die Skriftuurlike aspekte daarvan geboei is, terwyl die Vroeg-Humanisme meer geĩnteresseerd is in die vraag hoe die Vroeg-Christelike denkers terselfdertyd ook Romeine kon wees!

Hierdie vroeë Humanisme was hoofsaaklik 'n pedagogiese beweging wat in die verlede na 'n morele inspuiting vir wedergeboorte van kerk en godsdiens gesoek het.

Die latere Humanisme probeer nog steeds die skone ideale van die verlede órdroom. Hierdie denkers gaan egter verder in die geskiedenis terug. Die tydperk waarby hulle gaan kers opsteek, is nie meer die Patristiek nie maar die Griekse en Romeinse Oudheid.

Hier het ons 'n duidelike linkse tendens. Die vraag is nou nie meer (soos by die vroeë Humaniste) hoe dit moontlik is om tegelyk Christen en Romein te wees nie, maar waarom dit nie moontlik is om in jou denke (soos in die Antieke) deur en deur net Romein (dit wil sê pagaan) te wees nie. Die emansipasie vanuit kerklike en godsdienstige bindinge skry voort. Die outonome, selfversekerde, waardige, edelmoedige mens tree nog duideliker na vore.

Die Humanisme word gekenmerk deur 'n wetenskaplike, literêre en opvoedkundige ideaal op die studie van die Oudheid gebaseer. (Anders as die Reformasie wat meer 'n volksbeweging was, was dit dan ook meer beperk tot die kring van die intellektuele). Die Humanisme is die deurwerking van die Renaissance op die gebied van die wetenskappe. Dit bestaan egter nie bloot uit die groepering van 'n aantal vakke nie. Daaragter sit 'n nuwe lewensvisie. In sy lewensbeskouing droom die Humanis nie net van 'n aantal dissiplines nie maar ook van die eindresultaat van skoling daarin: 'n nuwe wêreld waarin die nuwe, outonome mens sal heers.

Spoedig het die Humaniste egter besef dat 'n glorieryke verlede wel oorgedroom kan word, maar dat studeerkamerdagdromery alleen nie voldoende is om 'n nuwe kultuur te bou nie. Repristinasie is tog nie die oplossing nie! Die uurwerk van die geskiedenis kon nie maar na willekeur teruggedraai word nie.

Te groot klem op die outoriteit van die antieke outeurs het bv. eie oorspronklikheid gekortwiek. En die edele mens mag nie geknel word nie! 
Die Renaissancemens ( $u$ sal merk dat ek nie skerp tussen $\mathrm{Hu}$ manisme en Renaissance onderskei nie) gee dus nog 'n verdere stap: Ons kan uit ons eie krag wedergebore word! Nie alleen die vroedvrou van die Christendom nie maar ook dié van die Antieke heidendom is nie nodig nie. Ons sal ons aan ons eie skoenveters optrek en sal by onsself kers opsteek!

Een van die antieke strominge wat by die nuwe lewensgevoel van die Renaissancemens pragtig ingepas het, was die Stoissisme, in die oudheid deur figure soos Cicero en Seneca verteenwoordig. Dit was 'n denke waarin die mens en sy onverstoorde sedelike pligsbetragting sentraal gestaan het. Van die "terug na die natuur" (i.p.v. na die Skrif, die genade) het die Renaissancedenkers gehou. Die Stoa het egter nie net die wette (logoi spermatikoi van die Logos) vir die morele lewe in die natuur gevind nie. Hierdie wette of matstawwe is ook in die mens se rede ingeplant. Die mens is dus basies sy eie wetgewer en outonoom. Die rasionalisme, in die kiem reeds by die Antieke Stoa aanwesig, word gretig deur die Renaissance aangegryp en sou spoedig daarna 'n leidende rol in die Westerse wêreld beklee.

As gevolg van die aanvanklike tendens om na die verlede terug te gryp het baie ander Antieke filosofiese strominge (soos die NeoPlatonisme, Aristotelisme, Pytagorisme, Epukurisme en Skeptisisme) in die loop van die vyftiende en sestiende eeu "revivals" belewe. Daarop kan ons egter nie ook ingaan nie. Ons aandag word nou gevra deur 'n heeltemal ander groep wat elders na die lig vir die nuwe tyd gaan soek het.

3. Die Reformasie: fakkeldraer van Abel.

Die Hervormers is ook siek van die skolastiese sintesedenke. Hulle breek egter daarmee om presies die teenoorgestelde rede as die Renaissance, naamlik sodat die Woord van God weer vry kan word. Hulle dink duidelik anti-sinteties regs.

Die Reformatore leer ook heelwat uit die oudheid. Soos die "voorlopers van die Hervorming" gryp hulle ook in baie opsigte na die Kerkvaders terug. Die motief is egter omdat hulle as verteenwoordigers van 'n suiwerder tydperk in die geskiedenis van die Christendom beskou word. So is Augustinus in die eerste plek vir Calvyn 'n gids terug na die Woord van God.

Die Reformasie soek sy lig duidelik elders. Nie by die antieke heidendom nie; nie by die selfwedergebore, verligte, edele, opgevoede, mondige mens wat die lig van sy eie verstand volg nie. Of jy nou die gesag by die pous soek of by die verligte mens, was vir die Reformatore ewe verkeerd.

Die lig kom vir hulle nie van onder uit die aarde nie maar van Bo. Die Reformasie het nie bloot historiese verandering op die horisontale vlak nagestreef nie maar religieuse verandering op die vertikale vlak van die verhouding tot God en sy wet; nie bekering tot die verlede of reaksie teen die verlede en bekering uit eie krag nie maar bekering deur God en tot sy Woord. Die absolute gesag kom al'non aan Hom toe. Sy woord is die enigste plek waar jy jou fakkel kan aansteek. 
4. Calvyn beproef die geeste van sy tyd.

Dit is verkeerd om - soos baie nog steeds geneig is om te doen - Calvyn uit piëteit as 'n soort sestiende-eeuse Melgisedek te sien: 'n mens sonder begin of agtergrond. Hy het in ' $n$ bepaalde tyd opgegroei en was in menige opsigte 'n kind van sy tyd. Hy het van sy jeug af daagliks met al die geestesstrominge van sy omgewing in kontak gekom. 'n Mens sou selfs kan sê dat sy denke gegroei het uit ' $n$ voortdurende poliloog wat hy met die verskillende denkstrominge gevoer het.

Dit sou verkeerd wees om Calvyn se denke bloot net uit buiteBybelse invloede te verklaar. Dit sou egter net so verkeerd wees om te beweer dat hy geen ander invloed as die van die Bybel ondergaan het nie.

Enkele opmerkings oor Calvyn en die Humanisme, Stoa en Platonisme ter illustrasie.

Humanisme. Volgens kenners is Calvyn veral deur daardie tipe Humanisme beĩnvloed waarin die Filologie as gevolg van die literêre ontwaking 'n belangrike rol gespeel het. Hierdie groep het in hulle terugkeer na die bronne 'n bepaalde historiese-filologiese metode ontwikkel wat 'n houding van eerbied teenoor die antieke tekste voorgeskryf het. Die historiese besef en die poging om objektief teenoor die bronne te staan en dit self te laat spreek was iets nuuts.

Calvyn het in hierdie opsig ontsettend veel aan die Humanisme te danke. Hy het 'n soortgelyke benadering teenoor die Skrif ingeneem. Dit was 'n geweldige stap vooruit dat hy in sy Skrifverklaring met die eeue-oue allegoriese eksegese gebreek het, want dit was ' $n$ belangrike metode waarop allerlei vreemde denkbeelde in die Bybel ingelees is en ' $n$ sintese tussen die Skrif en allerlei pagane opvattinge bewerk is.

Stoüsisme. Die feit dat Calvyn se heel eerste geskrif 'n kommentaar op Seneca se De Clementia was, toon aan hoe intiem hy van hierdie denkrigting kennis geneem het. Sommige beweer dat Calvyn se denke niks anders as "gedoopte Stoïsisme" is nie. Die ander uiterste word verteenwoordig deur diegene wat Calvyn van enige Stoĩsynse invloed hoegenaamd vrypleit.

'n Mens kan die begrip "invloed" natuurlik verskillend gebruik Self sien ek besliste, duidelike invloed van die Stoa op Calvyn se opvatting van 'n lex naturalis en, samehangend daarmee, op sy idee van semen religionis en conscientia (gewete).

Platonisme. In die navorsing op hierdie gebied het ons ook met ekstreme standpunte te make. Waar sommige per defectum sondig deur te beweer dat Calvyn die Platoniserende trek (van bv. Augustinus) heeltemal afgelê het, sondig ander per excessum deur die invloed van die Platonisme op Calvyn totaal te oorskat.

My eie tentatiewe navorsing op die gebied het my oortuig dat Calvyn se denke nie net formeel (woordgebruik) maar ook saaklik (inhoudelik) die invloed van Plato en die Neo-Platonisme ondergaan het. Sy mensbeskouing is seker die duidelikste bewys daarvan.

Ek sou egter nie so ver gaan om Calvyn 'n Platonis te noem nie. Dit sou 'n leermeester-leerling-verhouding veronderstel wat in hiergeval beslis nie bestaan nie. Wat Calvyn in Plato bruikbaar gevind 
het, het hy oorgeneem - sonder om 'n volgeling te word, gretig om sy meester se gedagtes te bevestig en besorg daaroor dat nie die geringste faset daarvan verander mag word nie.

\section{Samevatting.}

Die Renaissance, met al die wysgerige strominge wat dit in die sestiende eeu laat herleef het, was ten diepste 'n religieuse beweging na links, weg van die Woord van God en die God van die Woord. Calvyn se religieuse gerigtheid was na regs. Hy word deur 'n ander gees gedra.

Daarom moet 'n mens baie versigtig wees om nie bloot op grond van dieselfde woordgebruik of parallelle gedagtegange tot die gevolgtrekking te geraak dat Calvyn deur 'n betrokke wysgerige stelsel beinvloed is nie. ' $n$ Diepergaande studie is nodig waarin die twee stelsels (bv die hele antropologie) noukeurig en volledig vergelyk word.

In die algemeen kan gesê word dat Calvyn die filosofiese materiaal van sy tyd nie te ernstig geneem het nie. Hy gaan meestal op 'n merkwaardige nonchalante manier daarmee om. Sy gebruik van die filosofiese gedagtes van sy tyd is meer histories as sistematies. Hy gebruik dit eerder as illustrasie van die waarheid as 'n gids na die waarheid. Dit dra nie sy denke nie maar dra tot die verheldering, verduideliking van wat hy wil sê by.

Daarom is sy gebruik van Humanisme, Stoisisme en Platonisme ook nie sistematies nie maar eklekties. Sover ek weet, kry ons nêrens by hom 'n volgehoue sistematiese argumentasie om 'n bepaalde filosofie volledig te behandel en goed te praat nie.

Dit alles neem nie weg dat Calvyn op enkele punte van sy denke (bv. in sy natuurwetidee en mensbeskouing) tog diep in die filosofieë van sy tyd getrap het nie. Wie eerlik en onbevange dit wat Calvyn geskryf het, in die lig van die geskiedenis van die voorafgaande en kontemporêre denke van sy tyd lees, sal dit moet erken.

Calvyn se onafhanklikheid staan egter voorop, gewaarborg daardeur dat die Bron van sy denke die Woord van God was. Miskien moet ons Calvyn nie negatief toets aan die mate wat hy voor buiteBybelse invloede geswig het nie, maar eerder positief vra in hoe 'n mate Calvyn 'n bydrae gelewer het om die Woord van God weer reg te verstaan.

Indien $\mathrm{u}$ verder in hierdie onderwerp belangstel, kyk gerus na my boekie Die denkdekor van die Reformasie. 